\title{
Sağlık Okuryazarlığı: Kahramanmaraş Sütçü İmam Üniversitesi Sağlık Yönetimi Öğrencileri Üzerinde Bir Araştırma ${ }^{1}$
}

\author{
Abdullah SOYSAL \\ Prof. Dr., Kahramanmaraş Sütçü İmam Üniversitesi, \\ İktisadi ve İdari Bilimler Fakültesi, Sağl1k Yönetimi Bölümü \\ asoysal2005@hotmail.com \\ Orcid ID: https://orcid.org/0000-0001-6411-4988
}

\section{Eda OBUZ}

Kahramanmaraş Sütçü İmam Üniversitesi, Sosyal Bilimler Enstitüsü, Yüksek Lisans Öğrencisi, eda.obuz26@gmail.com

Orcid ID: https://orcid.org/0000-0002-0707-3531

\section{$\ddot{O ̈ z}$}

$\mathrm{Bu}$ çalışma Kahramanmaraş Sütçü İmam Üniversitesi Sağlık Yönetimi Bölümü Öğrencilerinin sağlık okuryazarlığı düzeylerini belirlemek amaciyla yapılmıştır. Araştırmanın örneklemini rastgele örnekleme yöntemiyle ulaşılan 114 öğrenci oluşturmuştur. Verilerin toplanmasında sosyo-demografik özelliklerin sorgulandığı anket formu ve Okyay vd. (2016) tarafından güvenilirlik ve geçerlilik çalışması yapılan "Türkiye Sağlık Okuryazarlı̆̆ Ölçeği-32 (TSOY32)" kullanılmıştır. Verilerin değerlendirilmesinde Mann Whitney U testi ve Kruskal Wallis $\mathrm{H}$ testi ile Spearman Korelasyon testinden yararlanılmıştır. Katılımcıların genel sağlı okuryazarlı̆g toplam puan ortalaması $67,53 \pm 15,66$ olarak bulunmuştur. Tedavi ve Hizmet alt boyutunda sağlık okuryazarlığı toplam puan ortalamas $33,45 \pm 8,63$ olarak bulunurken, Hastal1klardan Korunma ve Sağlığın Geliştirilmesi alt boyutunda toplam puan ortalaması $34,08 \pm 8,73$ olarak bulunmuştur. Katılımcıların \%95,6'sının genelde mükemmel sağlık okuryazarlığ düzeyine sahip oldukları, Tedavi ve Hizmet boyutunda \%28,9'unun yeterli düzeye sahip oldukları, Hastalıklardan Korunma ve Sağlığıı Geliştirilmesi boyutunda ise katılımcıların \%36,0 ile yeterli sağlık okuryazarlı̆̆ 1 düzeyine sahip oldukları görülmektedir. Çalışma içerisinde katılımcılardan toplanan verilerle yapılan analizler sonucunda öğrencilerin yaş, cinsiyet, sınıf düzeyi, öğrenim türü, sosyal güvence ve gelir düzeyleri ile sağlık okuryazarlı̆̆ 1

\footnotetext{
${ }^{1}$ Makale Geliş/Kabul Tarihi: 20.01.2020 / 09.09.2020

Künye Bilgisi: Soysal, A. ve Obuz, E. (2020). Sağllk Okuryazarlı̆̆ı: Kahramanmaraş Sütçü Imam Üniversitesi Sağlık Yönetimi Öğrencileri Üzerinde Bir Araştırma. Kahramanmaraş Sütçü İmam Üniversitesi Sosyal Bilimler Dergisi, 17 (2), 1198-1217. DOI: $10.33437 /$ ksusbd.677560
} 


\title{
A.Soysal-E.Obuz Sağlık Okuryazarlığı: Kahramanmaras Sütcü İmam...
}

düzeyi arasında genelde ve alt boyutlarında istatistiksel olarak anlamlı bir fark bulunmamıştır.

Anahtar Kelimeler: Sağl1k, Sağlık Okuryazarlığı, Sağlık Okuryazarlığı Düzeyi, Öğrenci.

\section{Health Literacy: A Study On Health Management Students Of Kahramanmaraş Sütçü İmam University}

\begin{abstract}
This study aims to examine the health literacy levels of health management department students of Kahramanmaraş Sütçü İmam University. The sample of the study consisted of 114 students reached using random sampling method. In the data collection, the questionnaire in which socio-demographic characteristics were questioned and "Turkey Health Literacy Scale-32 (Tsoy-32) the validity and reliability study of which was done by Okyay et al. (2016) were used. In data analysis, The Mann Whitney U test, Kruskal Wallis $\mathrm{H}$ test and Spearman Correlation tests were used. The mean total score of the general health literacy of the participants was found to be $67.53 \pm 15$.66. In the Dimension of Treatment and Service, the mean total score of health literacy was $33.45 \pm 8.63$ while the mean total score in the dimension of Disease Protection and Health Improvement was $34.08 \pm 8.73$. It was observed that $95.6 \%$ of the participants had excellent health literacy level, $28.9 \%$ of them had sufficient level of health literacy in Treatment and Service Dimension and 36.0\% of them had adequate health literacy level in Disease Protection and Health Improvement Dimension. As a result of the analyzes of the data collected from the participants, nostatistically significant difference was found between th estudents' age, gender, grade level, type of education, social security, income levels and health literacy levels.
\end{abstract}

Keywords: Health, Health Literacy, Health Literacy Level, Student.

\section{GİRIŞ}

Sağlık okuryazarlığı kavramını tanımlayabilmek ve anlayabilmek için öncelikle okuryazarlık kavramı üzerinde durmamız gerekmektedir. "Okuması 
yazması olan, öğrenim görmüş (kimse)" Türk Dil Kurumuna (TDK) göre okuryazar olarak tanımlanmaktadır (TDK, 2018).

Değişim ve gelişimin süreklileştiği şu zamanlarda yaşanan ekonomik, sosyal ve teknolojik gelişmeler, özellikle son 30-40 yıl içerisinde, birçok yaşam pratiğimizde olduğu gibi haberleşme şekillerimizde, okuma, yazma, dinleme/izleme biçimlerimizde ve metin algımızda önemli değişiklikler meydana getirmiştir. Bu durumun doğal bir sonucu olarak da geleneksel okuma ve yazma eylemleri çerçevesinde değerlendirilen okuryazarlık kavramının anlam sahası genişlemiştir(Tüzel, 2012). Geçmişte sadece okuma ve yazma faaliyetlerini yerine getirme eylemi olarak ifade edilen okuryazarlık zamanın değişimine ayak uydurmuş ve Balcı (2013) tarafından daha güncel bir şekilde, yaşam boyu öğrenme bilincini oluşturma, bu bilinci geliştirme, daha etkin öğrenme için bireylerin yeni beceriler kazanmalarını sağlamak olarak tanımlanmıştır.

Sağlık ve okuryazarlık kavramları arasında anlamlı bir ilişki bulunmaktadır. Okuma yazma bilmeyen bir bireyin sağlik alanında kendini ifade edebilmesi, sağlığını yönetmesi oldukça zordur. Ancak yüksek okuryazarlık düzeyine sahip olan bir bireyin, sağlık okuryazarlığı düzeyinin de kesinlikle yüksek olacağının düşünülmesi doğru değildir. Yapılan araştırmalardan da yola çıkılarak düşük okuryazarlığa sahip bir bireyin sağlık okuryazarlığının da düşük olması beklenirken, yüksek okuryazarlığa sahip her bireyden yüksek sağlık okuryazarlığı beklenemeyeceği sonucuna varılmıştır(Balçık vd.,2014).

Sağlık Bakanlığı'nın çalışmasında belirttiği üzere 1948 yılında Dünya Sağlık Örgütü Tüzüğü'nde sağlık, yalnızca hastalık veya sakatlığın olmaması durumu değil, fiziksel, sosyal ve ruhsal yönden tam bir iyilik hali şeklinde tanımlanmıştır (Türkiye Cumhuriyeti Sağlık Bakanlığı Temel Sağlık Hizmetleri Genel Müdürlüğü, 2011). Sağlık durumunun yani kişilerdeki tam iyilik halinin sağlanabilmesinde en büyük rol yine kişinin kendisine düşmektedir. Çünkü sağlık hizmet sunumu ne kadar kaliteli olursa olsun kişi bilinçli bir sağlık okuryazarlığ düzeyine sahip değilse sağliklı olma durumunu tam olarak sürdüremeyeceği gibi hastalandığı takdirde iyileşmekte de bilinçli bir hastaya göre daha fazla zorluk çekecektir.

Bilir (2013)'in çalışmasında ifade ettiği şekliyle sağlık okuryazarlığı, genel okur-yazarlık ile ilişkili olup insanların yaşamları boyunca sağlık hizmetleri ile ilgili konularda kanaat geliştirmek ve karar verebilmek, sağlıklarını korumak, sürdürmek ve geliştirmek, yaşam kalitesini yükseltmek için sağlık ile ilgili bilgi kaynaklarına ulaşabilme, sağlık ile ilgili bilgileri ve mesajları doğru olarak algılama ve anlama konularındaki istekleri ve kapasiteleridir. Sağlık kavramı hayatımızın tam olarak merkezinde yer almaktadır. Çünkü sağlığ 1 yerinde olmayan bireylerden iş hayatında, sosyal yaşamda veya aile ortamında tam olarak 


\section{A.Soysal-E.Obuz Sağlık Okuryazarlığı: Kahramanmaras Sütcü İmam...}

kedilerini ifade etmeleri veya diğer alanlarda iyi bir performans sergilemeleri beklenemez. Bu yüzden bireylerin yaşam kalitelerini iyileştirmeleri, hastalıkları önlemeleri ve sağlıklarını daha iyi bir hale getirebilmeleri için sağlık bilgilerine erişmeleri ve bu eriştikleri bilgileri anlama, değerlendirme ve uygulama yönünde kararlar alabilecek düzeyde olmaları gerekmektedir. $\mathrm{Bu}$ durum da sağlık okuryazarlığını ön plana çıkarmaktadır (Aslantekin ve Yumrutaş, 2014: 327).

Şimşek (2013) çalışmasında sağlık okuryazarlığının tarihçesiyle ilgili Simonds'un çocukların yalnız tarih, fizik gibi alanlarda okur-yazar olmamaları, sağlık alanında da okur-yazar olmaları gerektiğini ifade etmesi üzerine bu okullardaki sağlık eğitimi tartışmasında kavramın ortaya çıtığını belirtmektedir. Sağllk okuryazarlığı literatüre 1970'li yıllarda girmiş olmakla birlikte, tedavi hizmetlerinde ve halk sağlığı alanında önemi son yıllarda artmıştır. Özellikle 2005 yılı sonrasında sağlık okuryazarlı̆̆ 1 başlık ve konulu yapılan araştırma sayısında hızlı bir artış yaşanmıştır. Çalışmalarda artışın yaşanmasından yola çıkarak sağlık okuryazarlığının giderek önem kazandığı ve halk arasında tam olarak bu şekilde anılmasa bile bilinçli hasta kavramının oluşmaya başladığı gibi sonuçlara ulaşmak mümkündür.

Türkiye İstatistik Kurumu (TÜIK) (2018) verilerine bakılarak sağlık harcamalarının 2017 yılında \%17,4 oranında artarak, 140 milyar 647 milyon TL'ye ulaştığ 1 görülmektedir. Bu artışın yaşanmasında kişilerin sağlık hizmeti kullanımındaki dikkatsizliği önemli bir etkendir. Akbulut (2015)'un çalışmasında belirttiği üzere Türkiye de 2008 yılında acil servise başvurusu sayısı 80 milyon olarak gerçekleşmiş ve Sosyal Güvenlik Kurumu, durumu acil olmayan hastalarına acil servis kullanımına yönelik katkı payı ödeme uygulamasını başlatmıştır. Çalışma içerisinde sağlık okuryazarlığı düşüklügünün diğer ülkeler açısından da sağlık harcamaları maliyetlerini arttırdığı ifade edilmektedir. Bu durumun maliyetinin ABD'de yıllık 106 milyon dolar ile 238 milyon dolar arasında olduğu, İsviçre'de ise maliyetin 1.5 milyon frank olduğu hesaplanmıştır. Bilinçsiz hastanın bilinçsiz sağlık hizmeti kullanımını arttıracağı ve bununda sağlık harcamalarını arttıracağı dikkate alınarak sağlık okuryazarlığ 1 konusuna daha fazla dikkat çekilmelidir.

Hastalıkların arttığı ve yaşam süresinin giderek uzadığı günümüz şartlarında daha bilinçli hastalara ve bireylere ihtiyaç duyulmaktadır. Bu ihtiyacın giderilmesi noktasında eğitim önemli bir etkendir. Çünkü yetersiz sağlık okuryazarlığı düzeyi sadece bireylerin değil tüm toplumun ortak sorunudur. $\mathrm{Bu}$ sorunun çözümü sadece sunulan hizmetin kalitesi veya doktorların başarısıyla değil kişilerin bilinç düzeyinin yükseltilmesiyle sağlanabilir. Öz ve Roizen (2006)' in Siz Akıllı Hasta adlı kitabında belirttiği üzere sağlık hizmetlerinden daha verimli bir şekilde yararlanabilmek ancak hastaların kendilerini sağlık konusunda eğitmeleriyle mümkündür. Kitap içerisinde hazırlanan sorulara 
verilen cevaplarla ne oranda akıllı hasta olduğunuz saptanabilmektedir. Kitapta en iyi faydayı sağlamanın yolunun hasta doktor iş birliğinden geçtiği belirtilmekte bunun için de bilinçli hasta olmanın önemine vurgu yapılmaktadır. Hastaların bilinçli olmasının yanı sıra doktorlarında ülkenin sağlık okuryazarlığı düzeyinin farkında olarak hastaları bilgilendirmesi büyük öneme sahiptir.

Sezer (2012)'in çalışmasında belirttiği üzere sağlık okuryazarlığı Nutbeam tarafından üç düzeye ayrılarak ifade edilmiştir. Bunlar; temel (fonksiyonel) sağlık okuryazarlığı, interaktif sağlık okuryazarlığ ve kritik ( eleştirel) sağlık okuryazarlığıdır. Temel sağlık okuryazarlığı, sağlı hizmetlerini nasıl kullanacağını bilme, sözlü veya yazılı sağlık mesajlarını anlama, ilaç dozunu doğru hesaplayabilme gibi temel sağlık becerilerini içermektedir. İnteraktif sağlık okuryazarlığ ise mevcut sağlık bilgisiyle kendi sağlığını koruyabilme, besin içeriklerini okuma, egzersiz yapma, sağlık sorununa göre yardım alacağı sosyal destekleri bilme becerilerini içermektedir. En üst seviyede sağlık bilgisini gerektiren kritik sağlık okuryazarlığı düzeyi ise kendi sağlığı ve toplum sağlığ1 için var olan sağlık risklerini, sağlık sorunlarını tanımlayıp analiz etmeyi, çözüm için politika geliştirme süreçlerine katılmayı ve medyada çıkan sağlık haberlerini yorumlayabilme becerilerini içermektedir.

Bu çalışma Kahramanmaraş Sütçü İmam Üniversitesi Sağlık Yönetimi Bölümü Öğrencilerinin sağlık okuryazarlığı düzeylerini belirlenmek amaciyla yapılmıştır. Çalışma kapsamındaki öğrenciler üzerinde yapılan anketlerden elde edilen veriler ile yapılacak olan yorumların ve tavsiyelerin sağlik okuryazarlığının teşvik ve gelişimine katkıda bulunması hedeflenmiştir.

\section{Sağlık Okuryazarlığı Hakkında Literatür İncelemesi}

Sağlık okuryazarlığı gelişmişlik düzeyinin önemli bir göstergesidir. $\mathrm{Bu}$ yüzden konu üzerine özellikle yurt dışında çok fazla çalışma yapılmıştır. Ülkemizde araştırma sayısı yeterli bulunmasa da son zamanların dikkat çeken ve önemle üzerinde durulan konuları arasında yer almaktadır. Öneminin fark edilmesi üzerine ülkemizde sağlık okuryazarlığı alanındaki çalışma sayısında artış yaşanmıştır. Aşağıda konuyla ilgili olan çalışmalara yer verilmiştir.

Kutner vd. (2006) tarafindan Amerika'da yetişkinlerin sağlık okuryazarlığı düzeylerini belirlemek amacıyla çalışma yapılmıştır. Çalışma da sağlık okuryazarlığ 1 temel düzeyin altı, temel, orta ve yeterli düzeyde olmak üzere dört düzey kullanılarak ifade edilmiştir. Yetişkinlerin çoğunun (\%53) orta düzeyde, $\% 22$ 'lik kısmının temel düzeyde ve \%14'lük kısmının temel düzeyin altında sağlık okuryazarlığına sahip olduğu saptanmıştır. Çalışma içerisinde sağlık okuryazarlığ 1 ile temel değişkenler (yaş, eğitim durumu, ırk gibi) arasındaki ilişkilerde incelenmiş ve raporlanmıştır. 


\section{A.Soysal-E.Obuz Sağlık Okuryazarlığı: Kahramanmaras Sütcü İmam...}

Tokuda vd. (2009) tarafindan yapılan çalışma düşük sağlık okuryazarlığının yaygınlığını belirlemek ve Japon genel nüfusunun düşük sağlık okuryazarlığı ile fiziksel ve zihinsel refah arasındaki ilişkiyi araştırmak amacıyla yapılmıştır. Çalışmada sağlık okuryazarlığı düşük olan bireylerin yeterli sağlık okuryazarlığı olan bireylere göre daha düşük fiziksel ve zihinsel iyilik halinde oldukları ifade edilmiştir. Ayrıca çalışmada Japon yetişkinlerinde kendiliğinden bildirilen düşük sağlık okuryazarlığı oranı oldukça önemli bulunmuş ve bağımsız olarak daha zayıf fiziksel ve zihinsel refah ile ilişkili olduğu sonucuna ulaşılmıştır.

Avrupa Sağlık Okuryazarlığı Konsorsiyumu (2012) tarafindan Avrupa'da sağlık okuryazarlığı düzeyini belirlemek amaciyla sekiz Avrupa ülkesinden 7795 katılımcı ile yapılan çalışmada araştırmaya katılan kişilerin \%12'sinin yetersiz genel sağlık okuryazarlığ seviyelerine ve \%35'si ise sorunlu sağl1k okuryazarlığ seviyelerine sahip olduğu sonucuna ulaşılmıştır. Avrupa Sağlık Okuryazarlı̆̆ 1 Araştırması, tüm katılımcı ülkelerden elde ettiği verilerle sağlık okuryazarlığının daha eğitimli insanlarda önemli derecede daha yüksek olduğunu ortaya koymuştur.

Türk toplumunda erişkin nüfusun sağlık okuryazarlığ düzeyi ile yeterli ve mükemmel sağlık okuryazarlığı oranının belirlenmesi amacıyla Sağlık ve Sosyal Hizmet Çalışanları Sendikası (2014) tarafindan bir araştırma yapılmıştır. Araştırma, Türkiye'yi temsilen örnekleme dâhil edilen 12 bölgedeki 23 ilde rastgele seçilmiş 4924 kişinin katılımı ile gerçekleştirilmiştir. Araştırma sonucunda Türkiye'nin genel sağlık okuryazarlık indeksi 30,4 olarak bulunmuştur. Kategorik değerlendirmede toplumun \%64,6'sının "yetersiz" $(\% 24,5)$ veya "sorunlu" $(\% 40,1)$ sağlık okuryazarlığ saptanmıştır. Bu bulgu, yaklaşık 53 milyonluk Türkiye erişkin nüfusu göz önüne alındığında, yaklaşık 35 milyon kişinin "yetersiz" ve "sorunlu" sağlik okuryazarlığına sahip olduğuna işaret etmektedir.

Çin Ulusal Sağlık ve Aile Planlaması Komisyonu (2014)'nun kişilerin sağlik okuryazarlığını yükseltmek amacıyla yapmış olduğu pilot çalışmalar ışığında 2016 yılında Çin genelinde sağlık okuryazarlığı seviyesi \%11,58 iken, projenin uygulandığı ilçelerde bu oran \%19,57'ye ulaşmıştır.

Öztürk vd. (2015) tarafından aile sağlığ hizmetine başvuran hastaların demografik özellikleri ve sağlık okuryazarlıkları arasındaki ilişkinin belirlenmesi amacıyla yapılan bir diğer çalışmada ise, lisansüstü eğitim alanların daha düşük eğitim alanlara göre ilaç prospektüslerini daha fazla okuduğu, 999 TL ve altı geliri olan insanların daha az ilaç prospektüsü okuma alışkanlıklarının olduğu ve hastalıklarla ilgili broşürleri daha az anlayabildikleri sonucuna varılmıştır. Aynı zamanda erkek hastaların kadınlara göre ilaç prospektüslerini daha çok okudukları ve verilen broşürleri daha iyi anladıkları sonucuna ulaşılmıştır. 
Filiz (2015) tarafından çalışma, gebelerin sağlık okuryazarlığ 1 ve sağlık algısı düzeylerinin belirlenmesi aynı zamanda sağlık algısı ile sağlık okuryazarlı̆g 1 ilişkisinin belirlenmesi ve sağlık okuryazarlığını etkileyen faktörlerin ifade edilmesi amacıyla yapılmıştır. Çalışmadan elde edilen veriler incelendiğinde gebe kadınların, Sağlık Okuryazarlık ölçeğine göre \%29'u, NVS (NewestVitalSign) ölçeğine göre \%64'ü ve Halk Sağlığı Okuryazarlığına göre $\% 19$ 'unun okuryazarlık düzeyinin düşük olduğu sonucuna ulaşılmıştır. Sonuçlar göz önüne alınarak sağlık okuryazarlığı ile sağlık algısı arasında pozitif bir ilişki olduğu belirtilmiştir.

Türkoğlu (2016) tarafından Isparta il merkezinde yaşayan bireylerin sağl1k okuryazarlığı ve öz bakım düzeyini belirlemek ve sağlık okuryazarlığı ile öz bakım gücü arasındaki ilişkiyi ölçmek amacıyla yapılan çalışmada, sağlık okuryazarlığı ile öz bakım gücü arasında pozitif bir ilişki olduğu saptanmıştır. Çalışmada alternatif/tamamlayıcı tıbbı kullananların sağlık okuryazarlığı düzeyinin daha yüksek olduğu sonucuna ulaşılmıştır.

Çimen ve Temel (2017) tarafından kronik hastalığı olan yaşlı bireylerde sağlık okuryazarlığı ve sağlık algısı ilişkisini ve sağlık okuryazarlığını etkileyen faktörleri incelemek amacıyla yapılan çalışmada, kişilerin sağlık okuryazarlığı ölçeği puan ortalaması (87.96 \pm 13.89$)$ olarak bulunmuştur. Kadınların erkeklere, 65-74 yaş arasındakilerin diğer yaş gruplarına, evli bireylerin bekâr olanlara, lise ve üzeri eğitim almış grupların daha az eğitim alanlara, çalışanların çalışmayanlara göre puan ortalaması daha yüksektir. Çalı̧̧mada, kronik hastalık sayısının sağlık okuryazarlık düzeyini etkilemediği sonucuna varılmıştır.

Almaleh vd. (2017) tarafindan Mısır'da yapılan sağlık okuryazarlığına yönelik bir çalı̧̧ma da ise amaç AinShams Üniversitesi Hastanelerinde ayakta tedavi olan katılımcıların sağlık okuryazarlık düzeylerini ölçmek ve yetersiz sağlık okuryazarlığı ile ilişkili faktörleri araştırmaktır. Çalışmada kadınların yetersiz fonksiyonel sağlık okuryazarlığına sahip olma olasılıklarının daha yüksek olduğu ve fonksiyonel sağlık okuryazarlığı yetersiz olan katılımcıların yetersiz kapsamlı sağlık okuryazarlığına sahip olma olasılıklarının daha yüksek olduğu belirtilmiştir. Araştırma sonucunda çalışmaya dâhil edilen katılımcıların çoğunda sağlık okuryazarlığı sınırlı olarak bulunmuştur.

Çatı vd. (2018) tarafindan yapılan hastaların sağlık okuryazarlığı düzeylerinin memnuniyet düzeylerini ne oranda etkilediğini ortaya koymaya amaçlayan çalışmada, sağlık okuryazarlığı düzeyinin hasta memnuniyetini etkilediği belirtilmiş ve düşük sağlık okuryazarlığının hasta memnuniyetini olumsuz etkilediği sonucuna ulaşılmıştır.

Özer (2018) tarafından İstanbul'da sağlık hizmeti sunan kuruluşların kurumsal sağlık okuryazarlığ 1 ile hastaların sağlık okuryazarlığ 1 ve hasta memnuniyet 


\section{A.Soysal-E.Obuz Sağlık Okuryazarlığı: Kahramanmaras Sütcü İmam...}

düzeyleri arasındaki ilişkinin incelenmesi amacıyla yürütülen çalışmada, üniversite hastanesinde yatanlarda sağlık okuryazarlığı ve hasta memnuniyeti düzeyinin yüksek, devlet hastanesinde yatanlarda ise düşük olduğu belirtilmiştir. $\mathrm{Bu}$ durumdan üniversite hastanesindeki yüksek hasta memnuniyetinin gelişmiş kurumsal sağlık okuryazarlığı ile yakından ilişkili olduğu sonucuna varılmıştır. Dolayısıyla kurumsal sağlık okuryazarlığının hasta memnuniyeti üzerinde olumlu bir etkisinin olduğu ifade edilebilir.

Güven vd. (2018) tarafından Karabük Üniversitesi Sağlık Bilimleri Fakültesi öğrencilerinin sağlı okuryazarlığı düzeylerinin incelenmesi amaciyla yapılan çalışmada, öğrencilerin "yeterli yada mükemmel sağlık okuryazarlı̆̆ı" düzeyine sahip olma oranı ölçek toplamında \%55,7 olarak bulunmuştur. Çalışmanın sonuçları sağlık alanında eğitim gören öğrencilerin istenilen sağlık okuryazarlığı düzeyine sahip olmadığını göstermektedir.

\section{YÖNTEM}

Tanımlayıcı ve kesitsel tipteki bu çalışma Kahramanmaraş Sütçü İmam Üniversitesi Sağlık Yönetimi bölümü öğrencilerinin sağlık okuryazarlığ1 düzeylerinin incelenmesi amacıyla yapılmıştır. Araştırma evrenini Kahramanmaraş Sütçü İmam Üniversitesi Sağlık Yönetimi bölümünde okuyan tüm öğrenciler oluşturmaktadır. Rastgele örneklem yöntemiyle öğrencilere ulaşılmaya çalış1lmıştır. Veriler birebir görüşme yoluyla dolduran anketlerden elde edilmiştir. 13.12.2018-24.12.2018 tarihleri arasında uygulanan 120 anketin dağıtıldığg öğrenciler gönüllülük esasıyla doldurmuş oldukları 114 anket ile araştırma kapsamına dâhil edilmiştir.

Çalışmanın verileri öğrencilerin sosyo-demografik özelliklerinin sorgulandığı anket formu ve sağlık okuryazarlığına ilişkin ifadelerin bulunduğu "Türkiye Sağl1k Okuryazarlığı Ölçeği-32 (TSOY-32)” ile toplanmıştır. Ölçek, HLS-EU (EuropeanHealthLiteracySurvey) Çalışması Kavramsal Çerçevesi temel alınarak geliştirilen 32 soruluk yeni bir sağlık okuryazarlı̆̆ ölçeğidir. Okyay vd. (2016) tarafından ölçeğin geçerlilik ve güvenilirlik çalışması yapılmıştır. Kavramsal çerçeve, sağlıkla ilgili iki boyut (tedavi, hastalıklardan korunma ve sağlığın geliştirilmesi) ve sağlıkla ilgili karar verme ve uygulamalar ile ilgili dört bilgi edinme sürecini (ulaşma, anlama, değerlendirme ve kullanma/kullanmama) içermektedir. Her madde çok kolay, kolay, zor, çok zor ve fikrim yok şeklinde derecelendirilmiştir. Sorulara verilen cevaplara göre ölçekten 0-50 arasında değerler alınabilmektedir. 0; en düşük sağlık okuryazarlığını, 50; en yüksek sağlık okuryazarlığını göstermektedir. Sağlık okuryazarlığı düzeyi, elde edilen değere göre dört kategoride de değerlendirilebilmektedir (Güven vd.,2018:402);

0-25: yetersiz sağlık okuryazarlığını, 
>25-33: sorunlu/sınırlı sağlık okuryazarlığını,

>33-42: yeterli sağlık okuryazarlığını,

>42-50: mükemmel sağlık okuryazarlığını ifade etmektedir.

Çalışmada toplanan veriler bu dört kategoride değerlendirilerek ifade edilmiştir.

Ölçeğin Türkçe' de güvenirliği; iç tutarlık (Cronbach Alfa) ile incelenmiştir. Okyay vd. (2016) tarafından ölçeğin genel iç tutarlık katsayıs1; 0.927 olarak saptanmıştır.Bu çalışmada ise ölçeğin güvenilirlik analizi 0.912 olarak bulunmuştur.Bu da Kılıç (2016)'ın çalışmasında belirttiği üzere kabul edilebilir değer olan 0,70 'in oldukça üzerindedir.

Toplanan veriler SPSS 25 programında analiz edilmiştir. Uygun analiz yöntemlerini seçebilmek için öncelikle normal dağılım analizi yapılmış ve ifadelerin normal dağılım göstermediği sonucuna ulaşılmıştır. Bu yüzden çalışmada parametrik olmayan Mann Whitney U testi, Kruskal Wallis H testi ile Spearman Korelasyon testinden yararlanılmıştır.

Konuyla ilgili olarak aşağıdaki hipotezler oluşturulmuş ve test edilmiştir:

Hipotez 1: Katılımcıların yaşlarına göre sağlık okuryazarlığı düzeyleri anlamlı bir farklılık göstermektedir.

Hipotez 2: Katılımcıların cinsiyetlerine göre sağlık okuryazarlığı düzeyleri anlamlı bir farklılık göstermektedir.

Hipotez 3: Katılımcıların sınıf düzeylerine göre sağlık okuryazarlığı düzeyleri anlamlı bir farklılık göstermektedir.

Hipotez 4: Katılımcıların öğrenim türüne göre sağlık okuryazarlı̆̆ düzeyleri anlamlı bir farklılık göstermektedir.

Hipotez 5: Katılımcıların sosyal güvencelerine göre sağlık okuryazarlığı düzeyleri anlamlı bir farklılık göstermektedir.

Hipotez 6: Katılımcıların gelir düzeyine göre sağlık okuryazarlığı düzeyleri anlamlı bir farklılık göstermektedir.

\section{BULGULAR VE TARTIŞMA}

Araştırmaya katılan öğrencilerin sosyo-demografik özelliklerine ilişkin bulgular aşağıdaki Tablo1'de gösterilmektedir. 
A.Soysal-E.Obuz Sağlık Okuryazarlığı: Kahramanmaras Sütçü İmam...

Tablo 1: Öğrencilerin Sosyo-demografik Özelliklerinin Dağılımı

\begin{tabular}{|c|c|c|}
\hline & $\mathbf{N}$ & $\%$ \\
\hline \multicolumn{3}{|l|}{ Cinsiyet } \\
\hline Kadin & 79 & 69,3 \\
\hline Erkek & 35 & 30,7 \\
\hline \multicolumn{3}{|l|}{ Yaş } \\
\hline $17-20$ yaş arası & 49 & 43,0 \\
\hline $21-24$ yaş arası & 63 & 55,3 \\
\hline $25-28$ yaş arası & 2 & 1,8 \\
\hline \multicolumn{3}{|l|}{ Sınıf Düzeyi } \\
\hline Birinci Sinıf & 29 & 25,4 \\
\hline İkinci Sınıf & 20 & 17,5 \\
\hline Üçüncü Sınıf & 36 & 31,6 \\
\hline Dördüncü Sınıf & 29 & 25,4 \\
\hline \multicolumn{3}{|l|}{ Öğrenim Türü } \\
\hline Birinci Öğrenim & 57 & 50,0 \\
\hline İkinci Öğrenim & 57 & 50,0 \\
\hline \multicolumn{3}{|l|}{ Sosyal Güvence } \\
\hline Yok & 30 & 26,3 \\
\hline SGK & 74 & 64,9 \\
\hline Diğer & 10 & 8,8 \\
\hline \multicolumn{3}{|l|}{ Gelir Düzeyi } \\
\hline Gelir Giderden Az & 38 & 33,3 \\
\hline Gelir Gidere Denk & 64 & 56,1 \\
\hline Gelir Giderden Fazla & 12 & 10,5 \\
\hline
\end{tabular}

Çalışmaya katılan öğrencilerin \%69,3'ünü kadınlar oluşturmaktadır. \%55,3'lük kısmı 21-24 yaş aralığını, \%43'lük kısmı da 17-20 yaş aralığını, küçük bir kısım olan \%1,8' lik kısmı da 25-28 yaş aralığını oluşturmaktadır. Birinci sınıf öğrenciler \%25,4'lük kısmı oluştururken, \%17,5'lik kısmı ikinci sınıf öğrencileri, \%31,6'lık kısım üçüncü sınıf öğrencileri ve \%25,4'lük kısım ise dördüncü sınıf öğrencileri oluşturmaktadır. \%50'lik kısım birinci öğrenimlerdir. Öğrencilerin \%64,9'u Sosyal Güvenlik Kurumu'na (SGK) bağlı iken \%26,3'lük kısmın sosyal güvencesi yoktur. Katılımcilardan \%56,1'lik kısımda gelir gidere denk iken \%33,3'lük kısım da ise gelir giderden azdır. Çok az bir kısımda \%10,5 gelir giderden fazladır. 
Tablo 2. Türkiye Sağlık Okuryazarlığı Ölçeği-32 ve Alt Boyutlarının Puan Ortalamas1

\begin{tabular}{|c|c|c|c|c|c|}
\hline & $\mathbf{N}$ & Minimum & Maximum & $\begin{array}{l}\text { Mea } \\
\text { n }\end{array}$ & Std. Deviation \\
\hline Genel & 114 & 32,00 & 112,00 & $\begin{array}{l}67,5 \\
3\end{array}$ & 15,66 \\
\hline Tedavi ve Hizmet & 114 & 16,00 & 76,00 & $\begin{array}{l}33,4 \\
5\end{array}$ & 8,63 \\
\hline $\begin{array}{l}\text { Hastalıklardan } \\
\text { Korunma ve } \\
\text { Sağlığın } \\
\text { Geliștirilmesi }\end{array}$ & 114 & 16,00 & 53,00 & $\begin{array}{l}34,0 \\
8\end{array}$ & 8,73 \\
\hline
\end{tabular}

Yukarıdaki Tablo 2'de görüldüğü üzere katılımcıların genel sağl1k okuryazarlığ 1 toplam puan ortalamas $(\overline{\mathrm{X}}=67,53 \pm 15,66)$ olarak bulunmuştur. Tedavi ve Hizmet boyutunda sağl1k okuryazarlığ 1 toplam puan ortalamas $(\overline{\mathrm{X}}=$ $33,45 \pm 8,63)$ olarak bulunurken, Hastalıklardan Korunma ve Sağlığın Geliştirilmesi boyutunda toplam puan ortalaması $(\overline{\mathrm{X}}=34,08 \pm 8,73)$ olarak bulunmuştur. $\mathrm{Bu}$ konuda üniversite öğrencileri üzerine yapılan çalışmalar incelendiğinde; Güven vd.(2018)'nin Sağlık Bilimleri Fakültesi öğrencileri üzerinde yapmış oldukları çalışmada genel sağlı okuryazarlığı puanı $(\overline{\mathrm{X}}=34,53)$ olarak bulunmuştur. Yine aynı çalışmada Tedavi ve Hizmet boyutunun puan ortalaması $(\overline{\mathrm{X}}=35,40)$, ölçeğin genel puanından $(\overline{\mathrm{X}}=34,53)$ yüksek iken Hastalıklardan Korunma ve Sağlığın Geliştirilmesi boyutunun puan ortalaması $(\overline{\mathrm{X}}=33,83)$, ölçeğin genel puanından $(\overline{\mathrm{X}}=34,53)$ düşük bulunmuştur; Malatyalı ve Biçer (2018) tarafından Sivas Cumhuriyet Üniversitesi öğrencileri üzerinde yapılan çalışmada genel sağlık okuryazarlığı puan ortalaması $(\bar{X}=35,77)$ olarak bulunmuştur. Çalışmada Tedavi ve Hizmet boyutunun genel puanının, ölçeğin genel puanından yüksek olduğu, Hastalıklardan Korunma ve Sağlığın Geliştirilmesi boyutunun genel puanının, ölçeğin genel puanından düşük olduğu ifade edilmiştir. Görüldüğü üzere diğer çalışmalar incelendiğinde bulunan puan ortalamasının literatüre uygun olduğu ve katılımcıların sağl1k okuryazarlığ düzeylerinin yüksek olduğu ifade edilebilir.

Tablo 3. Katılımcıların Sağlık Okuryazarlığı Düzeyleri İle Yaş Arasında Yapılan Mann-Whitney U Testi Analizi

\begin{tabular}{cccc}
\hline 17-20 Yaş & 21-24 Yaş & Test & P değeri \\
Arası (N:49) & Arası (N:65) & degri \\
& & \\
& & $(\mathrm{Z})$ \\
\hline
\end{tabular}


A.Soysal-E.Obuz Sağlık Okuryazarlığı: Kahramanmaras Sütcü İmam...

\begin{tabular}{ccccc}
\hline & MeanRank & MeanRank & & \\
\hline Genel & 56,90 & 57,95 & $-0,169$ & 0,866 \\
\hline Tedavi ve Hizmet & 59,15 & 56,25 & $-0,464$ & 0,643 \\
\hline $\begin{array}{c}\text { Hastalıklardan } \\
\text { Korunma ve } \\
\text { Sağlığın } \\
\text { Geliştirilmesi }\end{array}$ & 54,13 & 60,04 & $-0,945$ & 0,344 \\
\hline
\end{tabular}

Yukarıdaki Tablo 3’te görüldüğü üzere katılımcıların yaşları ile sağlık okuryazarlığı düzeyleri arasında anlamlı bir fark bulunmamıştır. Değerli (2018)'nin yapmış olduğu çalışmada katılımcıların cevaplarına göre yaş ile sağlık okuryazarlığı düzeyleri arasında anlamlı bir fark bulunmuştur. Ayrıca çalışmada bulunan sonuçlara göre katılımcıların yaşlarının arttıkça sağlık okuryazarlığı düzeylerinin azalabileceği yönünde bir ifadede bulunulmuştur. İki çalışma arasında çıkan farkın çalışmaya dâhil edilen kişilerin yaş dağılımlarının farklı oluşundan kaynaklandığı düşünülmektedir.

Tablo 4. Katılımcıların Sağlık Okuryazarlı̆ğ Düzeyleri İle Cinsiyet Arasında Yapılan Mann-Whitney U Testi Analizi

\begin{tabular}{lllll}
\hline & $\begin{array}{l}\text { Erkek } \\
(\mathrm{N}: 35)\end{array}$ & Kadın (N:79) & $\begin{array}{l}\text { Test değeri } \\
(\mathrm{Z})\end{array}$ & $\begin{array}{l}\mathrm{P} \\
\text { değeri }\end{array}$ \\
\hline & MeanRank & MeanRank & & \\
\hline Genel & 63,09 & 55,03 & $-1,202$ & 0,230 \\
\hline \multicolumn{1}{|c|}{ Tedavi ve Hizmet } & 63,60 & 54,80 & $-1,313$ & 0,189 \\
\hline $\begin{array}{l}\text { Hastalıklardan } \\
\text { Korunma ve }\end{array}$ & 61,77 & 55,61 & $-0,919$ & 0,358 \\
$\begin{array}{l}\text { Sağlığın } \\
\text { Geliştirilmesi }\end{array}$ & & & & \\
\hline
\end{tabular}

Yukarıdaki Tablo 4'te görüldüğü üzere katılımcıların cinsiyetleri ile sağlık okuryazarlığı düzeyleri arasında anlamlı bir fark bulunmamıştır. Literatürde bu sonucu destekler nitelikte çalışmalar mevcut iken farklı sonuçlara ulaşılan çalışmalarda mevcuttur. Okyay vd.(2016)'nin, yapmış oldukları çalışmada da çalışmaya dâhil edilen grupların tamamında sağlık okuryazarlığı ve cinsiyet arasında anlamlı bir fark bulunmamış iken İnkaya vd. (2018)'nin yapmış oldukları çalışmada öğrencilerin cinsiyeti ile sağlık okuryazarlığı düzeyleri arasında anlamlı bir fark bulunduğu görülmüştür. Kız öğrencilerin sağlık okuryazarlığı ölçek puanının erkek öğrencilerden fazla olduğu ifade edilmiştir. 
Tablo 5. Katılımcıların Sağlık Okuryazarlığı Düzeyleri İle Öğrenim Türü Arasında Yapılan Mann-Whitney U Testi Analizi

\begin{tabular}{lllll}
\hline & $\begin{array}{l}\text { 1. Öğrenim } \\
\text { (N:57) }\end{array}$ & $\begin{array}{l}\text { 2.Öğrenim } \\
\text { (N:57) }\end{array}$ & $\begin{array}{l}\text { Test } \\
\text { değeri (Z) }\end{array}$ & $\begin{array}{l}\mathrm{P} \\
\text { değeri }\end{array}$ \\
\hline & MeanRank & MeanRank & & \\
\hline Genel & 56,47 & 58,53 & $-0,332$ & 0,740 \\
\hline Tedavi ve Hizmet & 57,78 & 57,22 & $-0,091$ & 0,928 \\
\hline $\begin{array}{l}\text { Hastaliklardan } \\
\text { Korunma ve }\end{array}$ & 56,60 & 58,40 & $-0,292$ & 0,770 \\
$\begin{array}{l}\text { Sağlı̆̆gn } \\
\text { Geliştirilmesi }\end{array}$ & & & & \\
\hline
\end{tabular}

Yukarıdaki Tablo 5'te katılımcıların öğrenim türü ile sağlık okuryazarlığı düzeyi arasında iki alt boyutta da anlamlı bir fark bulunmadığ 1 görülmektedir.

Tablo 6. Katılımcıların Sağlık Okuryazarlığı Düzeyleri ile Sınıf Düzeyleri Arasında Yapılan Kruskal-Wallis H Testi Analizi

\begin{tabular}{|c|c|c|c|c|c|c|}
\hline & $\begin{array}{l}\text { 1.sinif } \\
(\mathrm{N}: 29)\end{array}$ & $\begin{array}{l}2 . \text { sinif } \\
(\mathrm{N}: 20)\end{array}$ & $\begin{array}{l}3 \text { sinif } \\
(\mathrm{N}: 36)\end{array}$ & $\begin{array}{l}\text { 4.sinif } \\
(\mathrm{N}: 29)\end{array}$ & $\begin{array}{l}\text { Test } \\
\text { değeri }\end{array}$ & $\begin{array}{l}\mathrm{P} \\
\text { değeri }\end{array}$ \\
\hline & MeanRank & MeanRank & MeanRank & MeanRank & & \\
\hline Genel & 59,03 & 55,23 & 63,13 & 50,55 & 2,484 & 0,478 \\
\hline $\begin{array}{l}\text { Tedavi ve } \\
\text { Hizmet }\end{array}$ & 61,97 & 62,80 & 60,85 & 45,22 & 5,426 & 0,143 \\
\hline $\begin{array}{l}\text { Hastalıklardan } \\
\text { Korunma ve } \\
\text { Sağlığın } \\
\text { Geliştirilmesi }\end{array}$ & 55,38 & 51,28 & 65,08 & 54,50 & 2,968 & 0,397 \\
\hline
\end{tabular}

Yukarıdaki Tablo 6'da görüldüğü üzere katılımcıların sınıf düzeyleri ile sağlık okuryazarlığı düzeyleri arasında anlamlı bir fark bulunmamıştır. Güven vd. (2018)'nin çalışmasında da sınıflar arasında yapılan değerlendirmede anlamlı bir fark bulunmadığ 1 ifade edilmiştir.

Tablo 7. Katılımcıların Sağlık Okuryazarlığı Düzeyleri ile Sosyal Güvence Arasında Yapılan Kruskal- Wallis H Testi Analizi

\begin{tabular}{ccccc}
\hline SGK (N:74) & Yok (N:30) & Diğer (N:10) & Test değeri & $\begin{array}{l}\text { P } \\
\text { değeri }\end{array}$ \\
\hline MeanRank & MeanRank & MeanRank & & \\
\hline
\end{tabular}


A.Soysal-E.Obuz Sağlık Okuryazarlığı: Kahramanmaras Süitcü İmam...

\begin{tabular}{lccccc}
\hline Genel & 57,60 & 61,45 & 44,90 & 1,884 & 0,390 \\
\hline Tedavi ve & 54,78 & 68,83 & 43,60 & 5,809 & 0,055 \\
Hizmet & & & & & \\
\hline $\begin{array}{l}\text { Hastalıklardan } \\
\text { Korunma ve }\end{array}$ & 59,60 & 55,87 & 46,85 & 1,413 & 0,493 \\
$\begin{array}{l}\text { Sağl1 ğı̆ } \\
\text { Geliştirilmesi }\end{array}$ & & & & & \\
\hline
\end{tabular}

Yukarıdaki Tablo 7'de görüldügü üzere katılımcıların sosyal güvenceleri ile sağlık okuryazarlı̆̆ düzeyleri arasında anlamlı bir fark bulunmamıştır. Malatyalı ve Biçer (2018)'in yapmış olduğu çalışmada katılımcılar sosyal güvenceleri açısından incelediğinde anlamlı bir fark bulunmamıştır.

Tablo 8. Katılımcıların Sağlık Okuryazarlığı Düzeyleri ile Gelir Düzeyi Arasında Yapılan Kruskal- Wallis H Testi Analizi

\begin{tabular}{|c|c|c|c|c|c|}
\hline & $\begin{array}{l}\text { Gelir } \\
\text { Giderden } \\
\text { Az (N:38) }\end{array}$ & $\begin{array}{l}\text { Gelir Gidere } \\
\text { Denk (N:64) }\end{array}$ & $\begin{array}{l}\text { Gelir } \\
\text { Giderden } \\
\text { Fazla (N:12) }\end{array}$ & $\begin{array}{l}\text { Test } \\
\text { değeri }\end{array}$ & $\begin{array}{l}\mathrm{P} \\
\text { değeri }\end{array}$ \\
\hline & MeanRank & MeanRank & MeanRank & & \\
\hline Genel & 49,01 & 60,30 & 69,46 & 4,538 & 0,103 \\
\hline $\begin{array}{l}\text { Tedavi ve } \\
\text { Hizmet }\end{array}$ & 49,00 & 60,22 & 69,92 & 4,651 & 0,098 \\
\hline $\begin{array}{l}\text { Hastalıklardan } \\
\text { Korunma ve } \\
\text { Sağlığın } \\
\text { Geliştirilmesi }\end{array}$ & 49,93 & 59,93 & 68,50 & 3,673 & 0,159 \\
\hline
\end{tabular}

Yukarıdaki Tablo 8'de görüldüğü üzere katılımcıların gelir düzeyleri ile sağlık okuryazarlığ 1 düzeyleri arasında anlamlı bir fark bulunmamıştır. Değerli (2018) tarafından yapılan çalışmada da katılımcıların sağlık okuryazarlı̆̆g ile ilgili cevaplarında gelir gruplarına göre istatistiksel olarak anlamlı bir fark bulunmamıştır. Hashempour (2018) tarafindan yapılan başka bir araştırmada ise katılımcıların sağlı okuryazarlıkları ve aylık gelirleri arasında istatistiksel olarak anlamlı bir fark bulunduğu ifade edilmiştir. 
Tablo 9. Türkiye Sağlık Okuryazarlığı Ölçeği-32 İle Alt Boyutları Arasındaki Spearman Korelasyon Analizi Sonuçları

\begin{tabular}{cllll}
\hline & & Genel & $\begin{array}{l}\text { Tedavi ve } \\
\text { Hizmet }\end{array}$ & $\begin{array}{l}\text { Hastalıklardan } \\
\text { Korunma ve Sağlı̆̆ın } \\
\text { Geliştirilmesi }\end{array}$ \\
\hline Genel & $\mathrm{R}$ & 1,000 &, $893^{* *}$ &, $924^{* *}$ \\
\cline { 2 - 5 } & $\mathrm{P}$ &. &, 000 &, 000 \\
\hline Tedavi ve Hizmet & $\mathrm{R}$ &, $893^{* *}$ & 1,000 &, $682^{* *}$ \\
\cline { 2 - 5 } & $\mathrm{P}$ &, 000 &. &, 000 \\
\hline Hastalıklardan & $\mathrm{R}$ &, $924^{* *}$ &, $682^{* *}$ & 1,000 \\
\cline { 2 - 5 } $\begin{array}{c}\text { Korunma ve } \\
\text { Sağlığın } \\
\text { Geliştirilmesi }\end{array}$ & $\mathrm{P}$ &, 000 &, 000 &. \\
\hline
\end{tabular}

Yukarıdaki Tablo 9'da görüldüğü üzere sağlık okuryazarlı̆̆ ölçeği Tedavi ve Hizmet ile Hastalıklardan Korunma ve Sağlığın Geliştirilmesi alt boyutları arasında istatistiksel olarak anlamlı ve pozitif bir ilişki bulunmuştur (r:0,682; p:0,000). Katılımcıların sağlık okuryazarlığı düzeylerinin Tedavi ve Hizmet (r:0,893; p:0,000), Hastalıklardan Korunma ve Sağlığın Geliştirilmesi (r:0,924; p:0,000) alt boyutları ile istatiksel olarak anlamlı, güçlü ve pozitif yönlü bir ilişkinin olduğu belirlenmiştir. Katılımcıların Hastalıklardan Korunma ve Sağlığın Geliştirilmesi ile Tedavi ve Hizmet algılarının artmasıyla sağlık düzeylerinin de aynı şekilde artacağı söylenebilir.

Tablo 10. Katılımcıların Türkiye Sağlık Okuryazarlığı Ölçeği-32 Kategorik Sıklık Dağılımı

\begin{tabular}{ccccccccccc}
\hline & Yetersiz & \multicolumn{1}{c}{ Sorunlu } & Yeterli & \multicolumn{1}{c}{ Mükemmel } & Toplam \\
\hline & $\mathrm{N}$ & $\%$ & $\mathrm{~N}$ & $\%$ & $\mathrm{~N}$ & $\%$ & $\mathrm{~N}$ & $\%$ & $\mathrm{~N}$ & $\%$ \\
\hline Genel & 0 & 0 & 1 & 0,9 & 4 & 3,5 & 109 & 95,6 & 114 & 100 \\
\hline $\begin{array}{c}\text { Tedavi ve } \\
\text { Hizmet }\end{array}$ & 17 & 14,9 & 49 & 43,0 & 33 & 28,9 & 15 & 13,2 & 114 & 100 \\
\hline $\begin{array}{c}\text { Hastalıklardan } \\
\text { Korunma } \\
\begin{array}{c}\text { Ve Sağlığın } \\
\text { Geliştirilmesi }\end{array}\end{array}$ & 21 & 18,4 & 32 & 28,1 & 41 & 36,0 & 20 & 17,5 & 114 & 100 \\
\hline
\end{tabular}




\section{A.Soysal-E.Obuz Sağlık Okuryazarlığı: Kahramanmaras Sütcü İmam...}

Tablo 10'da katılımcıların \%95,6'sının genelde mükemmel sağlık okuryazarlığ düzeyine sahip oldukları, Tedavi ve Hizmet boyutunda ise $\% 43,0$ 'lık kısmın sorunlu-sınırlı sağlık okuryazarlığ düzeyine sahip iken \%28,9'unun yeterli düzeye sahip oldukları görülmektedir. Hastalıklardan Korunma ve Sağlığın Geliştirilmesi boyutunda ise çok yüksek bir oran olmasa da katılımcıların \%36,0 ile yeterli sağlık okuryazarlığı düzeyine sahip oldukları $\% 28,1^{\prime}$ lik bir kısmında sorunlu-sınırlı sağlık okuryazarlığı düzeyine sahip oldukları görülmektedir.

\section{SONUÇ VE ÖNERILER}

Sağlık okuryazarlığı, kişilerin bilinçli sağlık kararları vermek için gerekli sağlık bilgi ve hizmetlerini anlama, edinme ve işleme kapasitesinin derecesi olup, sağlıkla ilgili birçok konuyu içerisinde barındırmaktadır. Özellikle üniversite öğrencilerinin bu konuda daha bilinçli olması gerektiği düşüncesi üzerine yapılan bu çalışma sağlık eğitimi alanını da kapsayan sağlık yönetimi öğrencileri üzerinde yapılmıştır. Çalışma sonunda toplanan verilerden Kahramanmaraş Sütçü İmam Üniversitesi Sağl1k Yönetimi bölümünde okuyan öğrencilerin genel sağlık okuryazarlık durumu mükemmel düzeyde bulunurken, Tedavi ve Hizmet alt boyutunda çoğunluğun sorunlu-sınırlı sağlık okuryazarlığı düzeyine sahip olduğu sonucuna ulaşılmıştır. Hastalıklardan Korunma ve Sağlığın Geliştirilmesi alt boyutunda çok yüksek olmasa da yeterli sağlık okuryazarlığı oranı diğerlerinden fazladır.

Çalışma içerisinde katılımcılardan toplanan verilerle yapılan analizler sonucunda öğrencilerin yaş, cinsiyet, sınıf düzeyi, öğrenim türü, sosyal güvence ve gelir düzeyleri ile sağlık okuryazarllğg düzeyi arasında genelde ve alt boyutlarında istatistiksel olarak anlamlı bir fark bulunmamıştır. Yerli ve yabancı literatür bu yönde incelenmiş ve bulunan sonuçlar değerlendirilmiştir. $\mathrm{Bu}$ bağlamda yapılan çalışmada katılımcıların \%95,6'sının genelde mükemmel sağlık okuryazarlığı düzeyine sahip oldukları, Tedavi ve Hizmet boyutunda \%28,9'unun yeterli düzeye sahip oldukları, Hastalıklardan Korunma ve Sağlığın Geliştirilmesi boyutunda ise katılımcıların \%36,0 ile yeterli sağlık okuryazarlığı düzeyine sahip oldukları görülmektedir. Dolayısıyla bu çalışma Kutner vd. (2006) ve Çimen ve Temel (2017)'in çalışmalarında kişilerin sağlık okuryazarlığı düzeyinin yüksek olduğu yönündeki sonuçları desteklemektedir. Buna karşılık yapılan araştırmanın sonuçları, Avrupa Sağlı Okuryazarlığı Konsorsiyumu (2012), Sağlık ve Sosyal Hizmet Çalışanları Sendikası (2014) ile Filiz (2015)'in yaptıkları araştırma sonuçlarını desteklememektedir.

Çalışmada ortaya çıkan sonuçlar dikkate alınarak aşağıdaki öneriler siralanabilir: 
-Sağlık hizmetlerini daha etkin ve verimli sunabilmede sağlık hizmeti sunucularının sağlık okuryazarlı̆̆ı düzeyinin yüksek olması oldukça önemlidir. $\mathrm{Bu}$ anlamda sağlık alanında idari ve tıbbi olarak görev alacak kişilerin sağlik okuryazarlığı konusunda farkındalıklarını artırmak için örgün ve uzaktan eğitim veren tüm eğitim kurumlarının müfredatına sağlık okuryazarlığı dersi dahil edilmelidir.

- Yine yerel düzeydeki eğitim merkezlerinde ebeveyn sağlık okuryazarlığı eğitimi verilmelidir.

Çünkü eğitim ilk ailede başlar ve bilinçli bir ailede doğru yetiştirilen ve yönlendirilen çocukların da sağlık okuryazarlığı düzeylerinde artış olacağ 1 ve bu döngünün nesilden nesile devam edeceği ifade edilebilir.

-Eğitim konusunda yaşlılara ve çocuklara ayrıcalıklı bir eğitim verilmeli, özelikle de yaşlıların ilaç kullanımı konusundaki eğitimlerine dikkat çekilmelidir. Çocuklarda ise bu eğitimin anaokulu düzeyinde başlaması gerekmektedir.

-Toplu alanlarda sergilenecek konuyla ilgili güncel karikatürlerle de sağlık okuryazarlığ konusuna dikkat çekilebilir.

-Sağlık kurumları da hizmet içi eğitim programlarında kendi personellerine sağlık okuryazarlığı konusunda bilgilendirmelerde bulunabilirler. Ayrıca hastanede oluşturulan ekipler tarafından yatan hastalara sağlık okuryazarlığ 1 konusunda bilinç oluşturabilecek eğitimler verilmesi öneml olabilecektir.

-Sağlıkta ortaya çıkan ve hayatı kolaylaştıran mobil uygulamalar kişilere tanıtılarak faydalanmaları sağlanabilir. Bu konuda gerek devlet ve gerekse özel sektörde üretilen birçok mobil sağlık uygulaması kişilerde sağlık okuryazarlığı bilinci oluşturacak düzeydedir. Bu uygulamaların kullanımı özendirilip yaygınlaştırılabilir.

-Sağlık okuryazarllğı konusunda her kesime hitap edecek kitap, dergi, ebroşür vb. gibi tanıtıcı dokümanların sayısı arttırılmalı ve kişilerde bu konunun sosyal ve toplumsal bir konu olduğu bilinci oluşturulmalıdır.

-Günümüz şartlarında medyanın çok etkin rol oynadığı göz önüne alınarak toplumu sağlık okuryazarlığı konusunda aydınlatmada medya kanallarından da faydalanilmalidir.

\section{KAYNAKÇA}

Akbulut, Yasemin (2015). Sağlık Okuryazarlığının Sağlık Harcamaları ve Sağlık Hizmetleri Kullanımı Açısından Değerlendirilmesi, (Ed. Filiz 
A.Soysal-E.Obuz Sağlık Okuryazarlığı: Kahramanmaras Sütçü İmam...

Yıldırım ve Alev Keser), Ankara Üniversitesi Sağlık Bilimleri Fakültesi, Ankara, ss. 121-128.

Almaleh, Ranya, Helmy, Yousab, Farhat, E, Mohamod, Heba ve Abdelhafez, Ahmed (2017), Assessment of health literacy among outpatient clinic sattendees at Ain Shams University Hospitals, Egypt: a crosssectionalstudy. Public Health, 151, ss. 137-145.

Aslantekin, Filiz ve Yumrutaş, Mehmet (2014), Sağlık “Okuryazarlığı ve Ölçümü”, TAF Preventive Medicine Bulletin, 13(4), ss. 327-334.

Aşıc1, Murat (2009), "Kişisel ve Sosyal Bir Değer Olarak Okuryazarlık”, Değerler Eğitimi Dergisi, 7(17), ss. 9-26.

Balcı, Kürşat (2013), Öğretmen Adaylarının Bilgi Okuryazarlık Başarısı, Bilgisayar Öz Yeterlilik ve Bilgi Okuryazarlık Öz Yeterlilik Düzeyleri Arasındaki İlişki, Yüksek Lisans Tezi, Fırat Üniversitesi, Elazığ.

Balçık, Pınar Yalçın, Taşkaya, Serap ve Şahin, Bayram (2014), "Sağlık OkurYazarlığı”, TAF Preventive Medicine Bulletin, 13(4), ss. 321-326.

Bilir, Nazmi (2013), "Sağlık Okur-yazarlığı”, Turkısh Journal Of Publıc Health, 12(1), ss. 61-68.

china.com (2018), Çin'de Halk Sağlığına Yönelik Çalışmalar Güçleniyor, http://turkish.china.com/news/china/543/20180125/1189036.html (Erişim Tarihi: 31.12.2018).

Çatı, Kahraman, Karagöz, Yalçın, Yalman, Fuat ve Öcel, Yusuf (2018), "Sağlık Okuryazarlığının Hasta Memnuniyeti Üzerine Etkisi”, Ekonomik ve Sosyal Araştırmalar Dergisi, 14(1), ss. 67-88.

Çimen, Zühal ve Temel, Ayla Bayık (2017), Kronik Hastalığı Olan Yaşlı Bireylerde Sağlık Okuryazarlığı Ve Sağlık Algısı İlişkisi Ve Sağlık Okuryazarlığını Etkileyen Faktörlerin İncelenmesi, Ege Üniversitesi Hemşirelik Fakültesi Dergisi, 33(3), ss. 105-125.

Değerli, Hakan (2018), Toplumun Sağlık Okuryazarlık Düzeyinin Belirlenmesi Ve Sağlık Hizmetlerine Yönelik Algılarına Etkisinin İncelenmesi, Yüksek Lisans Tezi, Süleyman Demirel Üniversitesi, Isparta.

Filiz, Emel (2016), Sağlık Okuryazarlığının Gebelik Ve Sağlık Okuryazarlığı İle İlişkisi, Doktora Tezi, Selçuk Üniversitesi, Konya. 
Güven, Durdane Yılmaz, Bulut, Hülya ve Öztürk, Sercan (2018), "Sağlık Bilimleri Fakültesi Öğrencilerinin Sağlık Okuryazarlık Düzeylerinin İncelenmesi", Journel of History Cultureand Art Research, 7(2), ss. 400-409

Hashempour, Leila (2018), Sağlık Ve Diyabet Okuryazarlığı: Hacettepe Üniversitesi Hastaneleri Örneği, Doktora Tezi, Hacettepe Üniversitesi, Ankara.

İnkaya, Bahar ve Tüzer, Hilal (2018), "Bir Üniversitenin Sosyal ve Sağlık Bilimlerinde Okuyan Öğrencilerinin Sağlık Okuryazarlığı Durumunun İncelenmesi”, Kocaeli Medical Journal, 7(3), ss. 124-129.

Kılıç, Selim (2016), “Cranbach'ın Alfa Güvenilirlik Katsayısı”, Journal of Mood Disorders, 6(1), ss. 47-48.

Kickbusch, Ilona, Pelikan, Jürgen M., Apfel, Franklin ve Tsouros, Agis D. (2013), Sağlam Kanıtlar Sağlık Okuryazarlığı, (Çev. Türkiye Sağlıklı Kentler Birliği).

Malatyalı, İrem ve Biçer, Enis B. (2018), "Sağlık Okuryazarlık Düzeyinin Belirlenmesi: Sivas Cumhuriyet Üniversitesi Örneği”, Ankara Sağlık Hizmetleri Dergisi, 17(2), ss. 1-15.

National Center for Education Statistics (2006), “The health literacy of America'sadults: Results from the 2003 national assessment of adult literacy”, U.S. Department of Education, https://nces.ed.gov/pubs2006/2006483.pdf (Erişim Tarihi: 28.12.2018).

Sağlık ve Sosyal Hizmet Çalışanları Sendikası (2014), Türkiye Sağlık Okuryazarlığı Araştırması, SAĞLIK-SEN Yayınları, Ankara.

Sezer, Ayşe (2012), Sağlık Okuryazarlığının Sağlıklı Yaşam Biçimi Davranışları İle İlişsisi, Yüksek Lisans Tezi, Marmara Üniversitesi, İstanbul.

Şimşek, Zeynep (2013), "Sağlığı Geliştirmenin Tarihsel Gelişimi ve Örneklerle Sağlığı Geliştirme Stratejileri”, TAF Preventive Medicine Bulletin, 12(3), ss. 343-358.

Tokuda, Yasuharu, Doba, Nobutaka, Butler, James ve Paasche-Orlow, Michael (2009), "Healthliteracyandphysical and psychological well being in Japanese adults", Patient Education and Counseling, 75(3), ss. 411417. 
A.Soysal-E.Obuz Sağlık Okuryazarlığı: Kahramanmaras Sütcü İmam...

Türk Dil Kurumu (TDK) (2018), Okuryazar, http://www.tdk.gov.tr/index.php?option=com gts\&kelime=OKURYA ZAR (Erişim Tarihi: 19.12.2018).

Türkiye Cumhuriyeti Sağlık Bakanlığı Temel Sağlık Hizmetleri Genel Müdürlüğü (2011), Sağlığın Teşviki Ve Geliştirilmesi Sözlüğü (1. Baskı), Sağlık Bakanlığı Yayınları, Ankara.

Türkiye İstatistik Kurumu (2018), Sağlık Harcamaları İstatistikleri 2017, http://www.tuik.gov.tr/PreHaberBultenleri.do?id=27621 (Erişim Tarihi: 28.12.2018).

Türkoğlu, Çağdaş (2016), Sağlık Okuryazarlığı ile Öz Bakım Gücü Düzeyi Arasındaki İlişkinin İncelenmesi: Isparta İli Örneği, Yüksek Lisans Tezi, Süleyman Demirel Üniversitesi, Isparta.

Tüzel, Sait (2012), Medya Okuryazarlığı Eğitiminin Türkçe Dersleriyle İlişkilendirilmesi, Mustafa Kemal Üniversitesi Sosyal Bilimler Enstitüsü Dergisi, 9(12), ss. 81-96.

Okyay, Pınar (Ed.) ve Abacıgil, Filiz (Ed.) (2016), Türkiye Sağlık Okuryazarlığı Ölçekleri Güvenilirlik Ve Geçerlilik Çalışması, ağlık Bakanlığı Yayını, Ankara.

Öz, Mehmet ve Roizen, Michael F. (2006), Siz Akılı Hasta, Koridor Yayıncılık, İstanbul.

Öztürk, Zekai, Atilla, E.Asuman ve Koç, Elif (2015 ), Aile Sağlığı Merkezlerine Başvuran Hastaların Demografik Özellikleri Ve Sağlık Okur Yazarlıkları Arasındaki İliş̧inin Belirlenmesi, http://dergipark.gov.tr/download/article-file/200557 (Erişim Tarihi: 30.12.2018).

Özer, Orhan (2018), Sağlık Hizmeti Sunan Kuruluşların Kurumsal Sağlık Okuryazarlığı İle Hizmet Sundukları Kişilerin Sağlık Okuryazarlığı Ve Hasta Memnuniyet Düzeyleri Arasındaki İlişkinin İncelenmesi, Yüksek Lisans Tezi, Medipol Üniversitesi, İstanbul. 